\title{
ERRATUM
}

\section{Prenatal stress and risk of behavioral morbidity from age 2 to 14 years: The influence of the number, type, and timing of stressful life events-ERRATUM}

MONIQUE ROBINSON, EUGEN MATTES, WENDY H. ODDY, CRAIG E. PENNELL, ANKE VAN EEKELEN, NEIL J. MCLEAN, PETER JACOBY, JIANGHONG LI, NICHOLAS H. DE KLERK, STEPHEN R. ZUBRICK, FIONA J. STANLEY, AND JOHN P. NEWNHAM

University of Western Australia

doi:10.1017/S0954579411000241, published by Cambridge University Press, 20 April 2011

The affiliations for Stephen R. Zubrick and John P. Newnham were incorrect in the original version of this article (Robinson et al., 2011). We sincerely regret these errors and any problems they may have caused.

\section{Reference}

Robinson, M., Mattes, E., Oddy, W. H., Pennell, C. E., van Eekelen, A., McLean, N. J., et al. Prenatal stress and risk of behavioral morbidity from age 2 to 14 years: The influence of the number, type, and timing of stressful life events. Development and Psychopathology, $23,507-520$. 